\title{
Effect of therapeutic ultrasound of low intensity pulsed and continuous in fibroblastic cells in vitro
}

\author{
Priscila Daniele de Oliveira', Deise Aparecida Almeida Pires-Oliveira², Cristina Pacheco-Soares³, \\ Stheace Kelly Fernandes Szezerbaty', Ana Flávia Spadaccini', Larissa Dragonetti Bertin', Jéssica Lucio da Silva', \\ Adriele Flausino dos Santos ${ }^{4}$, Rodrigo Franco de Oliveira ${ }^{2}$
}

\begin{abstract}
Introduction: The ultrasound is widely used clinical practice focused on tissue repair, because it is a secure resource, minimally-invasive and low investment. However, despite the effects of ultrasound have been well described, the ideal relationship between dose and effect, still needs to be better elucidated and bounded. Objective: In this way, the objective of this study was to evaluate the influence of irradiation pulsed ultrasound and continuous in the viability of fibroblastic cells L929 in vitro. Method: The cells were distributed in TPP plates 12 wells in the concentration of $5 \times 10^{5}$ cells $/ \mu \mathrm{L}$ and subdivided into the following groups: G1: control (not received radiation), G2: irradiated to $0.5 \mathrm{~W} / \mathrm{cm}^{2}-30 \%$ and $\mathrm{G} 3$ : irradiated to $0.5 \mathrm{~W} / \mathrm{cm}^{2}-100 \%$. Then received ultrasonic irradiation with intervals of 24, 48 and 72 hours, and after 24 hours of each irradiation was performed MTT cytotoxicity cell. Results: Among the three groups analyzed, only the $\mathrm{G} 2$ group showed a significant difference between the time 48 and 72 hours $(p=0.05)$. In other times, despite variation in the percentage of viable cells, were not significant. When compared to peers at post-test, it was possible to observe a difference of $29 \%$ of viable cells between the groups G1 and G2 ( $p=0.05$ ). However, the biggest difference was observed between the groups G2 and G3 $(p=0.05)$. Conclusion: In this way, it can be concluded that irradiation pulsed ultrasound showed higher proliferation of fibroblasts L929 in time 48 hours, whereas in group irradiated in continuous mode, there was no statistically significant difference between the times.

Keywords: Fibroblasts, Cell Culture Techniques, Ultrasound.
\end{abstract}

\section{INTRODUCTION}

The ultrasound covers applications from industrial, diagnostic and even therapeutic, with notable repercussions in the scientific environment due to its wide use, because it is a safe, low-invasive and low investment for clinical practice. Especially when it comes to repairing tissues, in particular, present in the musculoskeletal system. ${ }^{(1,2)}$

In both modes, pulsed or continuous, therapeutic ultrasound (TUS) predicts responses such as analgesia, regression of edema and cicatrization acceleration in tissue injuries, thus providing a faster rate of return of function. ${ }^{(1)}$ Such responses come from two effects, thermal and athermic. ${ }^{(3)}$

Thus, the first, usually accompanied with higher intensities comes from the continuous mode and conditions the cell to an excitation that increases the metabolic activity, through the association between the stable cavitation and the acoustic transmission. ${ }^{(4,5)}$

On the other hand, the second, athermic, obtained in the output with pulses, is usually directed to the treatment of more severe or acute injuries, to improve the quality and speed of the recovery without increasing the local temperature. ${ }^{(6)}$

In this sense, several authors report the efficiency of low intensity ultrasound in the percentage increase of viable cells cultured in vitro, with acceleration of proliferation and, ${ }^{(7-9)}$ with the continuous, relevant therapeutic effects both in vivo and in vitro. ${ }^{(1,10)}$

Furthermore, in the continuous mode, effects on the expression of cartilage specific mRNA in chondrocyte culture, ${ }^{(11)}$ hypertrophy of muscle fibers, ${ }^{(1)}$ or with pulsed modulation in biosynthetic activity and expression of integrins ${ }^{(12)}$ and stimulation of anti-inflammatory systems in synovial membrane cells. ${ }^{(13)}$

It is worth mentioning that although the effects of ultrasound have already been well described, the ideal dose-effect relationship still needs to be better elucidated and delimited. ${ }^{(7-9,14)}$

Corresponding author: Rodrigo Franco de Oliveira. UNOPAR - Universidade do Norte do Paraná. Centro de Pesquisa em Ciências da Saúde. Laboratório de Cultura Celular. Av. Paris, 675. Jd. Piza, CEP: 86041-140, Londrina-PR. e-mail: rfrancoli@yahoo.com.br

2 Physiotherapist, PhD and Full Professor of the Master's and Doctorate Program Rehabilitation Sciences - UEL / UNOPAR, Londrina (PR), Brazil.

Full list of author information is available at the end of the article.

Financal Support: Fundação Nacional de Desenvolvimento do Ensino Superior Particular (Funadesp) and Coordenação de Aperfeiçoamento de Pessoal de Nível Superior. (Capes). 
In this way, this study aimed to evaluate the influence of pulsed and continuous ultrasound irradiation on the viability of L929 fibroblast cells in vitro.

\section{MATERIALS AND METHODS}

The analyzes carried out in the present study used as biological material L929 cells (Mouse conjunctive tissue - ATCC CCL-1 NCTC) (Instituto Adolfo Lutz - SP, Brasil). The study was approved by the Ethics Universidade Norte do Paraná (UNOPAR), under number protocol 462.478/2013.

\section{CELL CULTURE}

The fibroblast cells were cultured in $25 \mathrm{~cm}^{3}$ (TPP, Switzerland, Europe) utilizando meio DMEM (Dulbecco's Modified Eagle Medium) (Gibco ${ }^{\mathrm{TM}}$ - Invitrogen Corporation, Grand Island, USA) supplemented with 5\% FBS (Fetal Bovine Serum) (Cultilab, Brazil) and $1 \%$ of antibiotic and antimycotic, kept in a $\mathrm{CO}_{2}$ oven in $5 \%$ atmosphere at $37^{\circ} \mathrm{C}$. The cells used were subcultured whenever they reached $80 \%$ confluency. Mouse connective tissue cells were used in this experiment, according to the standard ISO 10993-5 who recommends the use of this in vitro cell line for cytotoxicity testing.

\section{ULTRASOUND IRRADIATION}

For ultrasonic irradiation, we used the equipment of the brand KLD ${ }^{\circledR}$ - (Biossistemas Equipamentos Eletrônicos Ltda, Amparo - Sao Paulo - Brasil), model Avatar III, with head of $1 \mathrm{MHz}$ and with effective radiation area (ERA) of $1 \mathrm{~cm}^{2}$, duly calibrated by the manufacturer and TPP 12 well plates, with $24 \mathrm{~mm}$ in diameter and $18 \mathrm{~mm}$ deep, containing $5 \times 10^{5}$ células $/ \mathrm{mL}$. In order to evaluate the ultrasound stimulation range, the following groups were created:

Group 1 (G1) - Control (no radiation),

Group 2 (G2) - irradiated at $0.5 \mathrm{~W} / \mathrm{cm}^{2}$ with pulse rate of $30 \%$ and frequency of $100 \mathrm{~Hz}$,

Group 3 (G3) - irradiated at $0.5 \mathrm{~W} / \mathrm{cm}^{2}$ with continuous pulse rate $(100 \%)$ and frequency of $100 \mathrm{~Hz}$.

\section{CELL CYTOTOXICITY TEST (MTT)}

The cytotoxicity experiments were evaluated by the method of MTT Brometo de [3-(4,5-dimetiltiazol)-2,5-difeniltetrazólio]. This quantitative method is used to evaluate cytotoxicity, proliferation and activation of viable cells with precision ${ }^{15}$. L929 cell cultures received ultrasonic irradiation at 24,48 and 72 hour intervals on TPP 12 well plates, and after 24 hours of each irradiation MTT test was performed according to the following assay: the culture medium was withdrawn from each well, added $500 \mu \mathrm{l}$ of MTT and incubated for 1 hour at $37^{\circ} \mathrm{C}$ in an atmosphere of $5 \%$ de $\mathrm{CO}_{2}$. The MTT was then withdrawn and added $500 \mu \mathrm{l}$ of DMSO (Dimetil sulfóxido) in each well. The plates were shaken for 15 minutes to solubilize the formazan crystals and subsequently the cells were transferred to a 96 well TPP plate and their concentration spectroscopically quantified by means of a microplate reader (Leitor ELISA SpectraCount - Packards Instrument, Offeburg - Alemanha), in the wavelength of $570 \mathrm{~nm}$.

\section{STATISTICAL ANALYSIS}

Data were expressed as averages and analyzed using the Shapiro Wilk test to verify normality, where all had a normal distribution. Therefore, a parametric path was chosen, opting for the ANOVA One Way test for intra and inter-groups analysis of variance and Tukey's post-test for peer evaluations.

\section{RESULTS}

The mean percentage values of each group and their respective standard deviations were tabulated and analyzed according to the incubation time, as shown in Table 1 . Among the three groups analyzed, only the group $\mathrm{G} 2\left(0.5 \mathrm{~W} / \mathrm{cm}^{2}-30 \%\right)$ presented a significant difference between the.

When analyzed according to the Tukey post-test, it was possible to observe the difference between the pairs. The $\mathrm{G} 2$ $\left(0.5 \mathrm{~W} / \mathrm{cm}^{2}-30 \%\right)$ presented a significant difference between the times of 48 and 72 hours ( $p=0.05)$, in which the value varied from $118 \%$ to $66 \%$, presenting a difference of $52 \%$ of viable cells. The $\mathrm{G} 3$ group $\left(0.5 \mathrm{~W} / \mathrm{cm}^{2}-100 \%\right)$ showed no difference between the times.

Already, comparative analysis between the groups in the different incubation times observed, evidenced a significant difference only in time 48 hours $(p=0.00)$. At the other times, although they presented variation in the percentage of viable cells, they were not significant. When compared to the post-test pairs, it was possible to observe a difference of $29 \%$ in viable cells between $\mathrm{G} 1$ (control) and $\mathrm{G} 2\left(0.5 \mathrm{~W} / \mathrm{cm}^{2}-30 \%\right)$ $(p=0.05)$. However, the greatest difference in this period was present between the groups pulsed at $30 \%(G 2)$ and continuous (G3), with $70 \%$ of cells being viable $(p=0.05)$, which can be observed in the Figure 1 .

Table 1 - Comparison of doses at different times of ultrasonic irradiation

\begin{tabular}{lcccc}
\hline & $\mathbf{2 4}$ hours & $\mathbf{4 8}$ hours & $\mathbf{7 2}$ hours & $\boldsymbol{p}$ \\
\hline $\mathbf{G 1}($ Control) & $85 \pm 15 \%$ & $89 \pm 12 \%$ & $82 \pm 18 \%$ & $\mathrm{~ns}$ \\
$\mathbf{G 2}\left(\mathbf{0 . 5} \mathbf{W} / \mathrm{cm}^{2}-\mathbf{3 0} \%\right)$ & $57 \pm 2 \%$ & $118 \pm 4 \%$ & $66 \pm 9 \%$ & $0.04 *$ \\
G3 $\left(\mathbf{0 . 5} \mathbf{W} / \mathrm{cm}^{2}-\mathbf{1 0 0 \% )}\right.$ & $57 \pm 6 \%$ & $48 \pm 1 \%$ & $54 \pm 12 \%$ & $\mathrm{~ns}$ \\
\hline
\end{tabular}

* significant values $(p \leq 0,05)$; ns: not significant. 


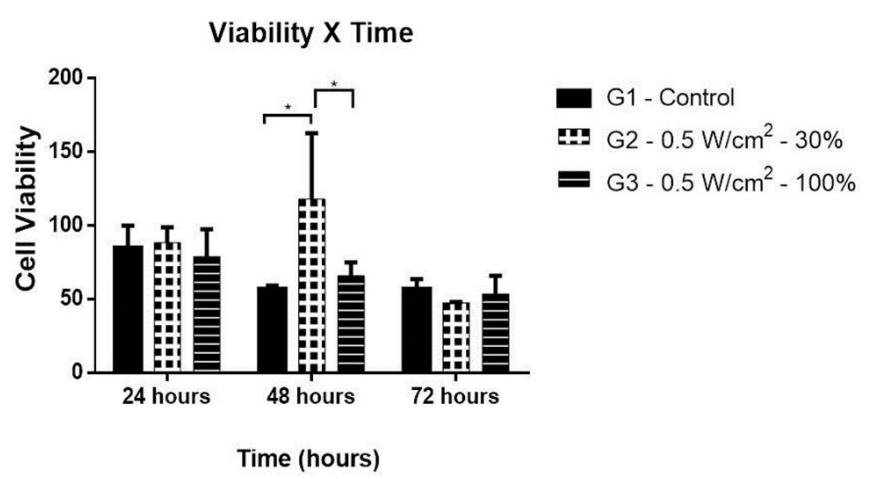

Figure 1 - Comparison of the percentage of cell proliferation among the groups at the times evaluated. ${ }^{*}$ significant values $(p \leq 0.05)$.

\section{DISCUSSION}

The objective of the present study was to evaluate the influence of ultrasonic irradiation in the intensity of $0.5 \mathrm{~W} / \mathrm{cm}^{2}$ in the pulsed pulse rate $30 \%$ and continuous (100\%) in the fibroblastic cell viability L929 in vitro. Among the data analyzed, there was a significant difference in group $0.5 \mathrm{~W} / \mathrm{cm}^{2}-30 \%$ between the times of 48 and 72 hours $(p<0.05)$, being also significant in the time 48 hours when compared to the other groups $(p=0.00)$.

From this perspective, low-intensity ultrasonic therapy, especially at a dose of $0.5 \mathrm{~W} / \mathrm{cm}^{2}$, has been studied in several tissues, both in vivo and in vitro. ${ }^{(7,12,16-19)}$ Thus, Piedade et al., ${ }^{(16)}$ in studies in vivo with Wistar rats, indicate a growth in myotube count when using the therapeutic ultrasound in this same dosimetry and pulse of $20 \%$.

As, Silva, et al., ${ }^{(17)}$ with similar intensity and pulse at $10 \%$, observed an increase in the number of tendon tenoblasts of the same animals. In contrast, the findings of Silveira et al.., ${ }^{(18)}$ in which the TUS was not significant in experiments aimed at the repair of bone tissue of dogs in vivo. Thus, against the results of the $\mathrm{G} 3$ group that did not express statistically differences significant by cell growth.

On the other hand, with in vitro techniques, other cells appear as a research target. As reported by Hasanova et al., ${ }^{(12)}$ they performed the counts of viable human articular chondrocytes by the MTT assay and found greater proliferation in the groups receiving continuous ultrasonic therapy four or eight times a day when purchased from the untreated groups.

In contrast, rabbit knee synovial membrane cells, under noninflammatory conditions, did not express any effect on proliferation when exposed to low intensity pulsed ultrasound, as did our $\mathrm{G} 2$ groups $\left(0.5 \mathrm{~W} / \mathrm{cm}^{2}-30 \%\right)$ from 48 to 72 hours and G3 $\left(0.5 \mathrm{~W} / \mathrm{cm}^{2}-100 \%\right)$, especially from 24 to 48 hours. ${ }^{(19)}$

These authors justify such results by stating that the biomodulating effects of ultrasound may have been minimized by high $\mathrm{CO}_{2}$ production or lack of nutrients by high concentrations of cells, especially when $100 \%$ confluence occurs, culminating in cellular apoptosis. ${ }^{(19,20)}$
Still, regarding the cellular percentage reduction in some groups, other authors corroborate with our findings, showing that the acoustic cavitation is intrinsically related to the TUS bioeffects and by generating numerous compressions and rarefaction can become unstable and trigger changes in the cellular size And membrane compliance, with even cellular implosions due to the increase of temperature and intracellular pressure, resulting in the decrease of viable cells irreversibly. ${ }^{(10,21,22)}$

Already, specifically in in vitro fibroblasts, Oliveira et al., ${ }^{(7)}$ reported that the statistical significance was only found in the group irradiated with ultrasound with analog dose $\left(0.5 \mathrm{~W} / \mathrm{cm}^{2}\right)$ and pulse rate of $10 \%(p=0.003)$. In this group, cell viability increased from 24 to 48 hours, and from 48 to 72 hours. Corroborating, with the results of the present study, in which group $2\left(0.5 \mathrm{~W} / \mathrm{cm}^{2}-30 \%\right)$, showed increased cell proliferation between 48 hours and 72 hours $(p=0.05)$.

Similarly, according to Demir et al., ${ }^{(23)}$ ultrasound has been shown to be efficient in stimulating fibroblasts and, with intensities of 0.1 to $0.5 \mathrm{~W} / \mathrm{cm}^{2}$, accelerates the inflammatory phase of tissue repair, contributing to the Indicate the use of therapeutic ultrasound in these parameters, when demonstrating increased cell proliferation, especially in the pulsed mode.

Likewise, according to Oliveira et al., ${ }^{(9)}$ irradiation at doses of 0,2 and $0,6 \mathrm{~W} / \mathrm{cm}^{2}$ in both the $10 \%$ and $20 \%$ pulse rates over the 72 hour period increased the viability of $\mathbf{2 9 2 9}$ fibroblast cells, being significantly higher than in the non-irradiated group.

This fact contrasts with the description of the percentage reduction of viable cells in comparison to the control in groups G2 $\left(0.5 \mathrm{~W} / \mathrm{cm}^{2}-30 \%\right)$ in 24 and 72 hours and G3 $\left(0.5 \mathrm{~W} / \mathrm{cm}^{2}-100 \%\right)$ in the three treatment times. In this respect, some authors have reported in cultured fibroblasts that the impact of the ultrasound waves $\left(1 \mathrm{~W} / \mathrm{cm}^{2}-20 \%\right)$ in their protocols was possibly higher than in a clinical situation, of the number, in a relation directly proportional to the time of exposure. ${ }^{(24)}$

Accordingly, scholars report that in clinical practice, the ability of tissues to attenuate, absorb and reflect sound waves causes the final energy received to be inferior to that offered by in vitro design, ${ }^{(24-26)}$ which Deyne and Kirsch-Volders concluded as the in vitro fibroblasts showed a decrease in viability, proportional to the time and number of ultrasonic exposures. ${ }^{(24)}$

Thus, taking into account that in culture the transducer-cells distance is usually delimited by the height of the well and by a column of culture medium, the height used in this $18 \mathrm{~mm}$ study may have influenced the reduction of viability in some groups and times, G2 $\left(0.5 \mathrm{~W} / \mathrm{cm}^{2}-30 \%\right)$ in 72 hours and $\mathrm{G} 3$ group $\left(0.5 \mathrm{~W} / \mathrm{cm}^{2}-100 \%\right)$. That said, the cellular reduction in the G3 continuous group may also be added to the thermal effect of the TUS caused by the mechanical energy transformation 
of its uninterrupted pulses through the attenuation by the tissue layers. ${ }^{(25-27)}$

Differently from Maeshige et al. ${ }^{(28)}$ who reported on the increase in the amount of proteins and mRNA expressed by mechanically stimulated dermal fibroblasts by TUS (0.1; 0.5 or $1 \mathrm{~W} / \mathrm{cm}^{2}$ e $20 \%$ ), at 24 and 48 hours. In parallel, human fibroblasts showed increase in cell proliferation tests with $5,15,30$ and $50 \mathrm{~mW} /$ and pulse in $30 \%$. $^{(29)}$

Also, corroborating with our findings, analyzes of 1929 fibroblastic viability and cellular organelles, such as cytoskeleton and endoplasmic reticulum (at doses 0.2 and $0.6 \mathrm{~W} / \mathrm{cm}^{2}$ and pulses of $10 \%$ and $20 \%$ ), proposed that ultrasonic irradiation pulsed, promotes the activation of cellular metabolism, accelerating the inflammatory phase of healing. ${ }^{(14,30)}$

Finally, other authors verified in a similar protocol, in vitro, with $L 929$ fibroblasts, a statistically significant effect on cell growth with pulsed and low intensity $\left(0.4 \mathrm{~W} / \mathrm{cm}^{2}\right)$, regimes, supporting the thesis that the interactions between intensity, frequency and pulse rate are strictly correlated to tissue repair phases. $^{(8)}$

\section{CONCLUSION}

Based on the results of this study, it was concluded that the definition of parameters such as time, intensity and especially the pulse regime may be fundamental for the best use of therapeutic ultrasound. Thus, pulsed ultrasonic irradiation had a greater proliferation of $\mathbf{2 9 2 9}$ fibroblasts in the 48 hour time, whereas in the continuous irradiated group there was no statistically significant difference between the times.

\section{AUTHORS' CONTRIBUTIONS}

PDO conducted the practical part of the experiments, collected and analyzed the data, wrote and edited the article. DAAPO, CPO and SKFS collaborated the practical part of the experiments, collected the date and writing methods. AFS and JLS participated in the elaboration of data analysis. LDB and AFS participated in the elaboration of part of discussion, RFO participated in orientation, writing and final review of the article.

\section{CONFLICT OF INTERESTS}

Nothing to declare.

\section{AUTHOR DETAILS}

${ }_{1}^{1}$ Physiotherapist, Master in Rehabilitation Sciences from the Universidade Estadual de Londrina (UEL)/Universidade do Norte do Paraná (UNOPAR), Londrina (PR), Brazil.

${ }^{3}$ Biologist, PhD and professor at the Universidade do Vale do Paraíba (UNIVAP) in the Department of Cell and Tissue Biology, São Jose dos Campos (SP), Brazil.

${ }^{4}$ Graduated in Physiotherapy from the Universidade do Norte do Paraná (UNOPAR), Londrina (PR), Brazil.

\section{REFERENCES}

1. Vásquez B, Navarrete J, Farfán E, Cantín M. Effect of pulsed and continuous therapeutic ultrasound on healthy skeletal muscle in rats. Int J Clin Exp Pathol. 2014;7(2):779-783.

2. Ghorayeb SR, Patel US, Walmsley AD, Scheven BA. Biophysical characterization of low-frequency ultrasound interaction with dental pulp stem cells. Journal of Therap Ultrasound. 2013;1(12):1-9.
3. Nussbaum EL, Locke M. Heat shock protein expression in rat skeletal muscle after repeated applications of pulsed and continuous ultrasound. Arch Phys Med Rehabil. 2007;88(6):785-90.

4. Watson T. Ultrasound in contemporary physiotherapy practice. Ultrasonics. 2008;48(4):321-329.

5. Watson T. Tissue repair: The current state of the art. Sportex-Medicine. 2006;28:8-12.

6. Watson T. Electrotherapy and tissue repair. Sportex-Medicine. 2006;29:713.

7. Oliveira PD, Pires-Oliveira DAA, Martinago CC, Poli-Frederico RC, Soares $\mathrm{CP}$, Oliveira RF. Effect of low-intensity pulsed ultrasound therapy on fibroblasts cell culture Phys Ther Research. 2015;22(2):112-118.

8. Bertin LD, Pires-Oliveira DAA, Oliveira PD, Serpeloni JA, Szezerbaty SKF, Santos JPM, Oliveira FR. A influência da irradiação ultrassônica de baixa intensidade em cultura de células fibroblásticas. Revista Terapia Manual. 2015;13:306-15.

9. Oliveira RF, Oliveira DAAP, Machado AHA, Silva NS, Magini M, PachecoSoares C. Assessment of fibroblast cell ssubmitted ultrasonic irradiation. Cell Biol Int. 2008;32(10):1329-35.

10. Domenici F, Giliberti C, Bedini A, Palomba R, Udroiu I, Di Giambattista $\mathrm{L}$, et al. Structural and permeability sensitivity of cells to low intensity ultrasound: Infrared and fluorescence evidence in vitro. Ultrasonics. 2014, 54:1020-1028.

11. Noriega S, Tarlan MS, Turner JA, Subramanian A. Intermittent Applications of Continuous Ultrasound on the Viability, Proliferation, Morphology, and Matrix Production of Chondrocytes in 3D Matrices. Tissue Engineering. 2007;13(3):611-8.

12. Hasanova GI, Noriega SE, Mamedov TG, Thakurta SG, Turner JA, Anuradha $S$. The effect of ultrasound stimulation on the gene and protein expression of chondrocytes seeded in chitosan scaffolds. J Tissue Eng Regen Med. 2011;5: 815-822.

13. Nakamura T, Fujihara S, Katsura T, Yamamoto K, Inubushi T, Tanimoto $\mathrm{K}$, et al. Effects of Low-Intensity Pulsed Ultrasound on the Expression and Activity of Hyaluronan Synthase and Hyaluronidase in IL-1b-Stimulated Synovial Cells. Annals of Biomedical Engineering. 2010;38(11):3363-3370.

14. Oliveira RF, Oliveira DAAP, Pacheco-Soares C. Efeito do ultrassom pulsado de baixa intensidade em culturas fibroblásticas L929. ConScienta e Saúde. 2008;7(3):315-321.

15. Mosmann T. Rapid colorimetric assay for cellular growth and survival: application to proliferation and cytotoxicity assays. J Immunol Methods. 1983;65(1-2):55-63.

16. Piedade MCB, Ferreira MA, Galhardo MS, Caldini EG, Battlehner CN, Toledo OMS. Effect of ultrasound therapy on the repair of Gastrocnemius muscle injury in rats. Ultrasonics. 2008;48(5):403:411.

17. Silva JMN, Carvalho JP, Júnior MJM, Arisawa EALS, Martin AA, Sá HP, et al. Estudo da ação do ultrassom terapêutico em modelo experimental de tendinite em ratos Wistar. ConScientia e Saúde. 2010;9(4):625:632.

18. Silveira DS, Pippill NL, Costa FS, Vescovi LA, Conti LMC, Weiss A, et al. O ultra-som terapêutico de $1 \mathrm{MHz}$, na dose de $0,5 \mathrm{~W} \mathrm{~cm}$, sobre o tecido ósseo de cães avaliado por densitometria óptica em imagens radiográficas. Ciência Rural. 2008;38(8):2225:2231.

19. Nakamura T, Fujihara S, Yamamoto-Nagata K, Katsura T, Inubushi T, Tanaka E. Low-Intensity Pulsed Ultrasound Reduces the Inflammatory Activity of Synovitis. Annals of Biomedical Engineering. 2011;39(12):2964-2971.

20. Uenaka K, Imai S, Ando K, Matsusue Y. Relation of low-intensity pulsed ultrasound to the cell density of scaffold-free cartilage in a high-density static semi-open culture system. J Orthop Sci. 2010;15:816-824.

21. Dubinsky TJ, Cuevas C, Dighe MK, Kolokythas O, Hwang JH. High intensity focused ultrasound: current potential and oncologic applications. Am J Roentgenol. 2008;190: 191-199.

22. Jens $\cup Q$, Desilets $C$, Martin BSP. High Intensity Focused Ultrasound. The European Aesthetic Guide Spring (2010). 
23. Demir H, Yaray S, Kirnap M, Yaray K. Comparison of the effects of laser and ultrasoundtreatmentson experimental woundhealing in rats. Journal of Rehabilitation Research Development. 2004;41(5):721-728.

24. Deyne PGD, Kirsch-Volders M. In Vitro Effects of Therapeutic Ultrasound on the Nucleus of Human Fibroblasts. Phys Ther. 1995;75(7): 629-634.

25. Marks R, Ghanagaraja S, Ghassemi M. Ultrasound for osteoarthritis of the knee: a systematic review. Physiotherapy. 2000;86:452-463.

26. Persson J, Stromqvist B, Zanoli G, Mccarthy I, Lidgren L. Ultrasound nucleolysis: an in vitro study. Ultrasound Med Biol. 2002;28:1189-1197.

27. Carrer VM, Setti JAP, Veronez DL, Moser AD. Continuous therapeutic ultrasound inthe healing process in rat skin. Fisioter Mov. 2015;28(4):751-758.
28. Maeshige N, Terashi H, Aoyama M, Torii K, Sugimoto M, Usami M. Effect of Ultrasound Irradiation on $\alpha$-SMA and TGF- $\beta 1$ Expression in Human Dermal Fibroblasts. Kobe J. Med. Sci. 2010;56(6):E242-E252.

29. Doan N, Reher P, Meghji S, Harris M. In vitro effects of therapeutic ultrasound on cell proliferation, protein synthesis and cytokine production by human fibroblasts, osteoblasts and monocytes. J Oral Maxillofac Surg. 1999;57:409-19.

30. Pires-Oliveira DA, De Oliveira RF, Magini M, Zangaro RA, Soares CP. Assessment of cytoskeleton and endoplasmatic reticulum of fibroblast cells submitted to low-level laser therapy and low-intensity pulsed ultrasound. Photomed Laser Surg. 2009;27(3):461-466. 